\title{
FEATURES OF THE INTERNATIONAL MSC EDUCATIONAL PROGRAMME IN ENVIRONMENTAL MANAGEMENT AND MODELLING
}

\author{
Petter PILESJO ${ }^{1}$, Ali MANSOURIAN ${ }^{1}$, Micael RUNNSTROM ${ }^{1}$, Roger GROTH ${ }^{1}$, \\ Alexandre GONCALVES ${ }^{2}$, Ana Paula FALCAO ${ }^{2}$, Magda Sofia Paraíso MATIAS ${ }^{2}$, \\ Louise van LEEUWEN ${ }^{3}$, Joan LOOIJEN ${ }^{3}$, Anton VRIELING ${ }^{3}$, Eimuntas PARŠELIÜNAS 4 , \\ Jūrate SUŽIEDELYTÉ-VISOCKIENE ${ }^{4}$, Darius POPOVAS ${ }^{4}$, Romuald OBUCHOVSKI ${ }^{4}$, \\ Dominykas ŠLIKAS ${ }^{4 *}$, Arūnas BÜGA ${ }^{4}$, Milad MANAFI ${ }^{5}$, Ara TOOMANIAN ${ }^{5}$, \\ Ahmed Anwar AMIN ${ }^{6}$, Mohammed Azeez SAEED 6 , Rund Hammoud Al BAZZAZ7, \\ Hussein Hamid HASSAN ${ }^{7}$, Hasan FEIZI $^{8}$, Alireza Karbasi ${ }^{8}$, Ehsan YASREBI ${ }^{8}$, \\ Toktam MOHTASHAMI ${ }^{8}$ \\ ${ }^{1}$ Lund University, 2 Paradisgatan, Lund, Sweden \\ ${ }^{2}$ Instituto Superior Tecnico, Lisbon, Portugal \\ ${ }^{3}$ Twente University, 5 Drienerlolaan, 7522 NB Enschede, Netherlands \\ ${ }^{4}$ Vilnius Gediminas Technical University, Sauletekio al. 11, Vilnius, Lithuania \\ ${ }^{5}$ Malayer University, Hamadan Province, Malayer, Arak - Malayer Hwy, Iran \\ ${ }^{6}$ Salahaddin University, Erbil, Iraq \\ ${ }^{7}$ University of Duhok, Zakho Street 38, 1006 AJ Duhok, Iraq \\ ${ }^{8}$ University of Torbat Heydarien, Razavi Khorasan Province, Torbat-e Heydariyeh, Iran
}

Received 01 November 2018; accepted 15 November 2018

\begin{abstract}
International Msc Educational Programme in Environmental Management and Modelling" (GeoNetC) is a European Commission funded project under ERASMUS+: Higher Education - International Capacity Building programme (Project No 561967-EPP-1-2015-1-SE-EPPKA2-CBHE-JP). It began in October 2015 and ended in October 2018. Initiated by the Lund University and partners from the Middle East countries, the GeoNetC project is an ambitious project aiming to match labour market needs with geospatial education offer both in Europe and Middle East countries.

The aim of this three-year project is to enable European universities to exchange best practices and innovation with each other and with Middle Eastern universities regarding the mismatch between Europe's geospatial education and training and the geospatial education in Middle East countries. There is a growing need for well-trained students at all levels - vocational, bachelors, masters - in the field of geospatial technologies. Obviously there is a growing number of jobs available in land surveying, mapping data collection, data processing, data delivery and turning data into information in both European and Middle East countries.

Through cooperation, all partners will improve the quality of their respective academic programs. The European partners will make their courses more attractive and well adjusted for students from the Middle East. As well, they will increase the general quality and add state-of-the-art learning components to their offerings, and the partners from the region will significantly increase the academic level and quality in the education they provide. There will be spin-offs into other subjects than environment/Geomatics, since both the pedagogic models developed (e.g. e-Learning) and communication and administrative tools can be used throughout the partner universities. Therefore, this partnership cooperation will be of great value to Partner Countries as well as to Programme Countries.

A number of distance learning courses/modules are developed jointly by partner institutions in Europe and the Middle East. The main aim of the network is to promote the use of spatial information and earth observation for environmental management and modelling through capacity building and institutional development, via a network in which all partners would contribute from their own positions of strength.

All 13 modules are following EU higher education standards regarding e.g. ECTS, and learning outcomes. The outcome of the project, in terms of courses/modules, will be freely used among the partners, with the possibilities of offering individual courses or a whole MSc programme, whether individually or together.
\end{abstract}

*Corresponding author. E-mail: dominykas.slikas@vgtu.lt 
All produced material was evaluated/quality controlled by an external evaluation group of independent experts within environmental management and modelling, higher education, as well as pedagogy.

Keywords: higher education, geospatial education, geoinformation system, well-trained student, distance learning system.

\section{Introduction}

The main objective of GeoNetC project is to create a sustainable capacity building programme in environmental management and modelling, to improve the quality and accessibility of higher education in two Middle East countries - Iran and Iraq. E-Learning courses based on identified needs and the labour market analysis, and society will benefit in terms of accessibility and quality. The management of higher education will be improved through the development and use of student-teacher-admin communication and reporting tools.

The lead partner, project coordinator is Lund University (Lund, Sweden). Partner universities are: Twente University (Enschede, Netherlands), Vilnius Gediminas technical university (Vilnius, Lithuania), Instituto Superior Tecnico (Lisboa, Portugal), Malayer University (Malayer, Iran), Salahaddin University (Erbil, Iraq), University of Duhok (Duhok, Iraq), University of Torbat-Heydarien (Torbat-Heidarieh, Iran). Project has number of associated partners: University of Tehran (Tehran, Iran), K. N. Toosi University of Technology (Tehran, Iran), Saffron Research Institute (Torbat-Heidarieh, Iran), Applied Geomatics Sweden AB (Lund, Sweden), GeoInfoSolutions BV (Almelo, Netherlands), Farasheen Organization For Environment (Zakho, Iraq), SajGostar-Caspian (Torbat-Heidarieh, Iran), Science \& Research Branch, Islamic Azad University (Tehran, Iran).

Iran and Iraq are countries where project consortium can make a significant impact, by enhancing political, cultural, educational and economic links between the EU and the region, as well as by disseminating EU social and democratic values. This partnership is uniquely positioned to maximize the opportunities for, and delivery of, successful capacity building. The specific objective of the project is to improve the level of competences and skills of high education in the region by developing, adapting, and delivering state of the art eLearning courses focusing on environmental modelling and climate change/food security. The extensive alumni and contact network of our partners, ensures that the demand for, and relevance and quality of graduates and courses will be properly evaluated. Staff training will be part of course development, including skills in geo-information science and earth observation, providing added value in finding solutions to climate change and food security challenges.

The course material to be developed will build upon existing courses used by the EU-partners, modified to meet the requirements (academically as well as pedagogically) of the Partner Countries (Parseliunas, Sponberg, \& Stankevicius, 2005; Antman, Larson, Pilesjö, \& Mårtensson, 2006; Pilesjö, Skidmore, Kooiman, \& Mårtensson,
2007; Sponberg et al., 2007; Dijkstra et al., 2014, 2015). An additional output of the project will be 13 highly relevant courses/modules (all together 120 ECTS) to be used by the project partners.

\section{Methodology}

Developing and using e-Learning materials is an academic, pedagogic and technological challenge (Antman et al., 2006; Pilesjö et al., 2007; Sponberg et al., 2007). The use of information-communication technologies (ICT) are needed when distributing learning materials by the Internet, and Internet based communication between students and teachers is essential for learning success (Antman et al., 2006; Pilesjö et al., 2007; Sponberg et al., 2007; Dijkstra et al., 2014, 2015). ICT tools for marking exercises/exams, and administrative tools for following student progress, are also needed. Existing ICT solutions will be adjusted to regional needs and staff will be trained throughout the project period.

E-Learning can be used to increase accessibility and internationalisation in higher education. Properly developed courses, based on content and pedagogy used by world leading partners, combined with extensive market investigations, tested by pilot students and external experts, increase quality and relevance (SužiedelyteVisockienè, Puzienè, Stanionis, \& Tumelienè, 2016; Ragauskas, Bručas, \& Sužiedelytè-Visockienè, 2016; Sužiedelytė-Visockienė, Bručas, Bagdžiūnaitè, Puzienė, Stanionis, \& Ragauskas, 2016; Sužiedelytė-Visockienė, Bagdžiūnaitè, Malys, \& Malienè, 2015; Rajabi, Pilesjo, Shirzadi, Fadaei, \& Mansourian, 2016; Rajabi, Mansourian, Pilesjo, \& Bazmany, 2014; Farnaghi \& Mansourian, 2013a, 2013b; Ardakani, Valadan Zoej, Mohammadzadeh, \& Mansourian, 2011; Dehghani, Valadan Zoej, Entezam, Mansourian, \& Saatchi, 2009; Moura, Cambra, \& Gonçalves, 2017; Falcão, Matias, Pestana, Gonçalves, \& Heleno, 2016; Alavipanah, Hamzeh, Jeihouni, \& Toomanian, 2017; Jeihouni, Alavipanah, Toomanian, \& Hamzeh, 2015; Jeihouni, Toomanian, Alavipanah, Shahabi, \& Bazdar, 2015; Toomanian, Harrie, Mansourian, \& Pilesjo, 2013; Asare-Kyei, Forkour, \& Venus, 2015; Girma Gebrekidan, de Bie, Skidmore, Venus, \& Bongers, 2016; Patel, Parida, Venus, Saha, \& Dadhwal, 2013; Chemura, van Duren, \& van Leeuwen, 2015; Hussin et al., 2014). New communication and administrative tools will build capacity within management. The courses to be developed are new and innovative, and will allow the partners to offer a unique Master of Science (MSc) degree courses.

Specific Project Objectives are:

- develop e-Learning courses (with the possibility of a full MSc program) in environmental management and modelling, with a focus on climate change and food security, based on needs assessment, 
- develop and adapt tools for facilitating student teacher - administrator communication and administration,

- increase awareness and acceptance of distance e-Learning,

- improve competence and knowledge in e-Learning,

- improve awareness regarding climate change and food security issues, and the use of geo-information to mitigate problems,

- improve international cooperation within these fields,

- improve employability for graduated students,

- feed the labour market with relevant and skilled graduates,

- involve more and new stakeholders in education in the field.

Accessibility of higher education is a challenge in countries like Iran and Iraq, with large populations, long distances between students and universities, and some-

Table 1. List of courses and lead/partners, to be developed in GeoNetC Project

\begin{tabular}{|c|c|c|c|c|}
\hline No & Course Name & ECTS & Lead & Partners \\
\hline 1 & GIS, Introduction & 15 & $\mathrm{LU}$ & IST, UD, TU, MU \\
\hline 2 & GIS, advanced & 15 & $\mathrm{LU}$ & $\begin{array}{l}\text { IST, UD, TU, } \\
\text { MU, VGTU }\end{array}$ \\
\hline 3 & $\begin{array}{l}\text { GIS and Statistical } \\
\text { Analysis for } \\
\text { Environmental } \\
\text { Modelling }\end{array}$ & 7.5 & $\mathrm{LU}$ & MU, UD \\
\hline 4 & Open Source GIS & 7.5 & MU & VGTU \\
\hline 5 & $\begin{array}{l}\text { RS \& GIS and } \\
\text { Climate Change }\end{array}$ & 7.5 & UT & SU, UD, TU \\
\hline 6 & $\begin{array}{l}\text { Spatial Data } \\
\text { Infrastructure } \\
\text { (SDI) }\end{array}$ & 7.5 & $\begin{array}{l}\mathrm{LU} \\
\mathrm{MU}\end{array}$ & UD \\
\hline 7 & \begin{tabular}{|l|} 
GIS and \\
Distributed \\
Hydrology \\
Modelling \\
\end{tabular} & 7.5 & $\mathrm{LU}$ & SU, UD, TU \\
\hline 8 & $\begin{array}{l}\text { Geospatial Web } \\
\text { Services }\end{array}$ & 7.5 & MU & UD, TU, LU \\
\hline 9 & $\begin{array}{l}\text { RS \& GIS Applied } \\
\text { to Changes in the } \\
\text { Environment }\end{array}$ & 7.5 & UT & UD, SU \\
\hline 10 & $\begin{array}{l}\text { RS \& GIS for } \\
\text { Food Security }\end{array}$ & 7.5 & UT & MU, TU, SU, UD \\
\hline 11 & $\begin{array}{l}\text { Research } \\
\text { Methodology }\end{array}$ & 7.5 & $\mathrm{LU}$ & UD, MU, SU, UT \\
\hline 12 & $\begin{array}{l}\text { RS of } \\
\text { Environmental } \\
\text { Parameters } \\
\end{array}$ & 7.5 & UT & IST, DU, SU \\
\hline 13 & Introduction to RS & 7.5 & IST & UT, UD, TU, SU \\
\hline 14 & Thesis & 30 & $\mathrm{LU}$ & all \\
\hline
\end{tabular}

Note: IST: Instituto Superior Tecnico, LU: Lund University, MU: Malayer University, SU: Salahaddin University, TU: Torbat University, UD: University of Duhok, UT: University of Twente, VGTU: Vilnius Gediminas Technical University. times security problems. Some of these issues can be mitigated through e-Learning. This project does this, and also develops ICT based communication and administrative tools, improving management of courses and students. New pedagogic approaches are key, combining experiences and focusing on students from the region.

\section{Results}

The results of the project in total could be split into three parts: 1) Development of GIS course material adapted to flexible learning methods based on ICT, 2) New methods of building up course modules for the adaptation to specific target groups, 3) A strengthened international network concerning GIS and Remote Sensing, resulting in future closer cooperation between partners.

The main target groups for the courses are ordinary students in higher education as well as professionals. The course material is adjustable according to educational level, technical support and area of interest of the target group. Every course consists of the theoretical material and practical exercises.

\subsection{Courses}

The following 13 courses+Thesis are developed, all together constituting a two-years studying programme, 120 ECTS in total (Table 1).

GIS introduction, GIS advance courses and Thesis work are mandatory courses, and 8 courses could be chosen freely from 11 courses according to the student needs.

\subsection{Mobility for teaching, training and/or project research activities}

Pilot students passed the courses for evaluation purposes. They did not receive a degree, but they got a diploma from the coordinating university (Lund). Students were from Europe, Iran, and Iraq.

Also, Iraqi partners have already submitted all the courses to the Ministry of Higher Education for the permission and license. This means that the developed courses and the Bologna process hopefully will be promoted and implemented in Iraq soon enough to maybe award pilot students "real credits" from Iraq.

\subsection{Quality assurance}

Quality is of extremely high importance, for the project as a whole as well as for the individual partners. Apart from the discussions with the stakeholders, and the evaluation of proposed courses by "pilot students", quality will be guaranteed through the implementation of the courses at the partner universities. For example, all courses to be developed were received the quality assurance from Lund University (LU) in Sweden, in order to be ready to launch at LU. This procedure is thorough and guarantees a high standard. Since the same accreditation process will be carried out at all (or almost all) other 
partner universities during the project time, this guaranties a high quality but also divers (in term of target group and culture) product.

\subsection{Awareness raising, dissemination, sustainability and exploitation of the project results}

Based on the information from both Iranian and Iraqi partners, the courses and the dedicated time for them, as well as the number of lectures and exercises and the dedicated time for them, are very close to the existing higher education system standards in both Iran and Iraq. So their adoption and usage will be easy. The closeness of the two systems facilitates promoting the Bologna system in Iran and Iraq in the future.

LU coordinating group and Malayer University had a meeting with Iranian Ministry of Higher Education in December 2016, where they presented the GeoNetC project. Both Malayer and Torbat Universities are in regular contact with the ministry about its benefits and its progress. To our knowledge, currently Acting Minister of Foreign Affairs is fully aware of the activities. The situation is also similar in Iraq. This will hopefully guarantee awareness raising, dissemination, sustainability, and exploitation of the project, beyond the possibilities and efforts made by the individual partners.

\subsection{Visibility}

Project partners have created a web site for the project: www.geonetc.net (Figure 1); University of Duhok (UoD), Iraq, is in charge of technical implementation and maintenance of the website.

The website's content is:

1. Information on the Erasmus Plus in general.

2. Information on the GeoNetC project.

3. Information on all the partners of GeoNetC and links to their websites.

4. Activities that has been implemented so far, as well as planned activities.
5. Courses; the names of the courses as well as the development process and information about course content.

6. Other outcomes of the projects this far.

7. How to contact us.

The website contains links to the partner universities and the partner universities have link to the project website for visibility. Whenever a project partner, and this is extra important for the partners from Iran and Iraq, has a presentation in their own country or outside, they mention the website and the GeoNetC project.

Continuous evaluation of theoretical as well as pedagogic content of the courses will assure broad applicability. The cooperation between the universities will also provide possibilities to strength multidisciplinary international research and education within the European society and Middle East countries as well.

\section{Acknowledgements}

The authors wish to thank the European Commission for funded project under ERASMUS+ Higher Education International Capacity Building programme (Project No. 561967-EPP-1-2015-1-SE-EPPKA2-CBHE-JP).

\section{Conclusions}

The GeoNetC project has offered the cooperating partners an unique opportunity to exchange training concepts and personal teaching experience. Sometimes this exchange has not been without effort but the general impression expressed by the partners from six countries is that the process has been very positive and profitable for everybody. So the project has created links between several EU universities and Middle East universities.

Full MSc programme was constructed and 13 courses were developed and tested, including Thesis writing. The outcomes of the project is the high level content, new netbased pedagogic method suited for accessing target groups

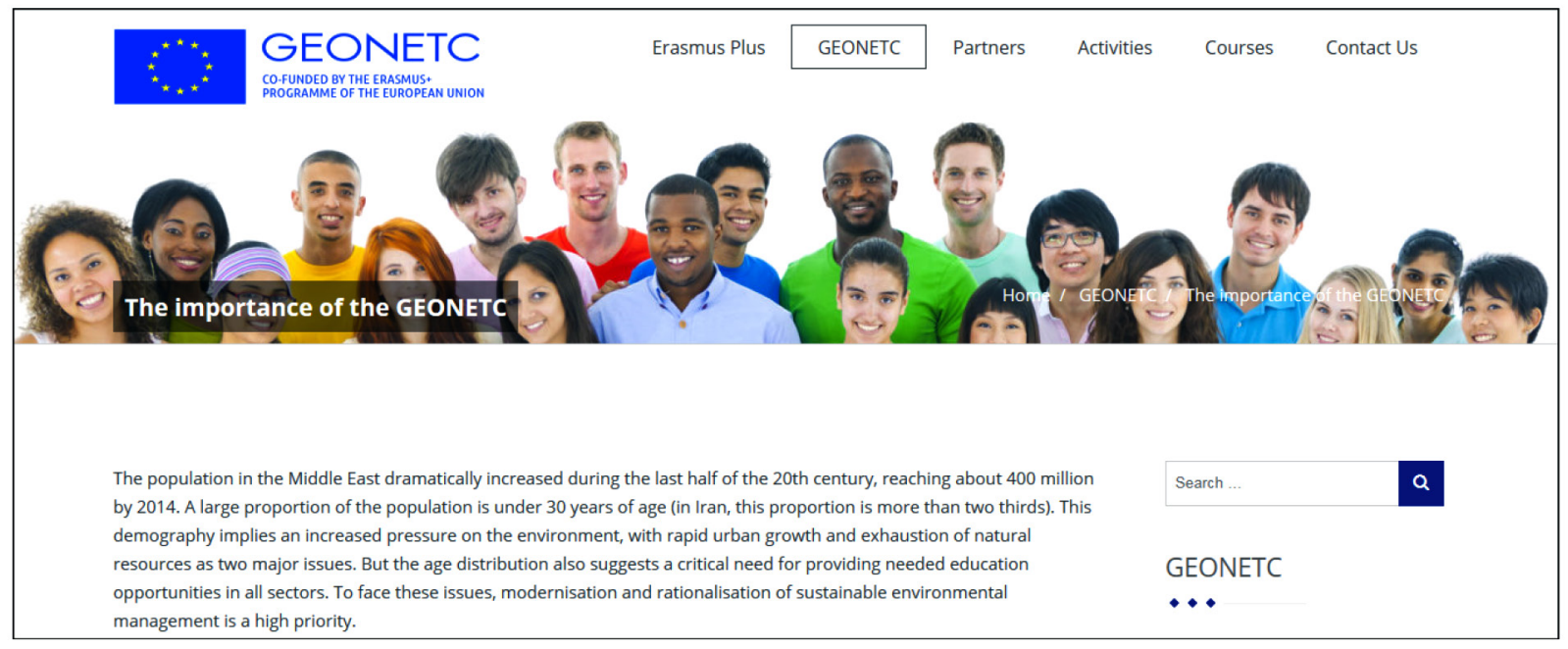

Figure 1. First page of GeoNetC web site 
of great diversity as regards pedagogic traditions, access to computers and bandwidth internet. Cooperation between the institutions will, certainly, give higher level courses than the individual institutions could possibly themselves.

Quality of courses was undergo quality assurance from Lund University (LU) in Sweden, in order to be ready to launch at LU. This procedure is thorough and guarantees a high standard.

Some of the GeoNetC project courses are new for Iran and Iraq. There are no doubts, that project will promote the Bologna system in Iran and Iraq in the future.

\section{References}

Alavipanah, S. K., Hamzeh, S., Jeihouni, M., \& Toomanian, A. (2017). Quantitative assessment of Urmia Lake water using spaceborne multisensor data and 3D modeling. Environmental Monitoring and Assessment, 189(11), 572.

Antman, L., Larson, L., Pilesjö, P., \& Mårtensson, U. (2006). Experiences from the LUMA-GIS eLearning master's program: Student perspective and pedagogic models. In [Host publication title missing], Fifth European GIS Education Seminar, Krakow, Poland.

Ardakani, A. S., Valadan Zoej, M. J., Mohammadzadeh, A., \& Mansourian, A. (2011). Spatial and temporal analysis of fires detected by MODIS data in northern IRAN from 2001 to 2008. IEEE Journal of Selected Topics in Applied Earth Observations and Remote Sensing, 4(1), 216-225. https://doi.org/10.1109/JSTARS.2010.2088111

Asare-Kyei, D. K., Forkour, G., \& Venus, V. (2015). Modeling flood hazard zones at the sub-district level with the rational model integrated with GIS and remote sensing approaches. Water, 7(7), 3531-3564. https://doi.org/10.3390/w7073531

Chemura, A., van Duren, I. C., \& van Leeuwen, L. M. (2015). Determination of the age of oil palm from crown projection area detected from WorldView-2 multispectral remote sensing data: the case of Ejisu-Juaben district, Ghana. ISPRS Journal of Photogrammetry and Remote Sensing, 100, 118-127. https://doi.org/10.1016/j.isprsjprs.2014.07.013

Dehghani, M., Valadan Zoej, M. J., Entezam, I., Mansourian, A., \& Saatchi, S. (2009). InSAR monitoring of progressive land subsidence in Neyshabour, Northeast Iran. Geophysical Journal International, 178, 47-56.

https://doi.org/10.1111/j.1365-246X.2009.04135.x

Dijkstra, P., Pirlot, J. Y., Velichkov, D., Paršeliūnas, E., Wijngaarde, M., Donert, K., Frigne, D., Westerbeek, H., Levoleger, K., Popovas, D., Obuchovski, R., Šlikas, D., \& Būga, A. (2015, July 6-8). Promoting of the geospatial skills: first results of the Geoskills plus project of the Leonardo Da Vinci programme. In EDULEARN 15 Proceedings, 7th International Conference on Education and New Learning Technologies, Barcelona, Spain (pp. 7270-7280). Valencia: IATED.

Dijkstra, P., Pirlot, J. Y., Velichkov, D., Paršeliūnas, E., Wijngaarde, M., Donert, K., Frigne, D., Westerbeek, H., Levoleger, K., Popovas, D., Obuchovski, R., Šlikas, D., \& Būga, A. (2014, July 7-9). Promoting of the geospatial skills: introduction into Geoskills plus project of the Leonardo da Vinci programme. In EDULEARN 14, 6th International Conference on Education and New Learning Technologies, Barcelona, Spain, [CD] (pp. 7587-7596). Valencia: IATED.

Falcão, A. P., Matias, M. P., Pestana, R., Gonçalves, A. B., \& Heleno, S. (2016). Methodology to combine topography and bathymetry datasets for hydrodynamic simulations: Case of Tagus River. Journal of Surveying Engineering, 142(4). Article ID 05016005.

https://doi.org/10.1061/(ASCE)SU.1943-5428.0000192

Farnaghi, M., \& Mansourian, A. (2013a). Automatic composition of WSMO based geospatial semantic web services using artificial intelligence planning. Journal of Spatial Science, 58(2), 235-250. https://doi.org/10.1080/14498596.2013.815148

Farnaghi, M., \& Mansourian, A. (2013b). Disaster planning using automated composition of semantic OGC web services: A case study in sheltering. Computers, Environment and Urban Systems, 41, 204-218.

https://doi.org/10.1016/j.compenvurbsys.2013.06.003

Girma Gebrekidan, A., de Bie, C. A. J. M., Skidmore, A. K., Venus, V., \& Bongers, F. (2016). Hyper-temporal SPOT-NDVI dataset parameterization captures species distributions. International Journal of Geographical Information Science, 30(1), 89-107. https://doi.org/10.1080/13658816.2015.1082565

Hussin, Y. A., Gilani, H., van Leeuwen, L. M., Murthy, M. S. R., Shah, R., Baral, S., \& Qamer, F. M. (2014). Evaluation of object - based image analysis techniques on very high-resolution satellite image for biomass estimation in a watershed of hilly forest of Nepal. Applied Geomatics, 6(1), 59-68. https://doi.org/10.1007/s12518-014-0126-z

Jeihouni, M., Alavipanah, S. K., Toomanian, A., \& Hamzeh, S. (2015). Assessing the spatio-temporal variations of Tabriz plane aquifer salinization and its relation with Urmia lake water level. Journal of Fundamental and Applied Life Sciences, 5(3), 1228-1236.

Jeihouni, M., Toomanian, A., Alavipanah, S. K., Shahabi, M., \& Bazdar, S. (2015). An application of MC-SDSS for water supply management during a drought crisis. Environmental Monitoring and Assessment, 187(7), 396. https://doi.org/10.1007/s10661-015-4643-y

Moura, F., Cambra, P., \& Gonçalves, A. B. (2017). Measuring walkability for distinct pedestrian groups with a participatory assessment method: A case study in Lisbon. Landscape and Urban Planning, 157, 282-296.

https://doi.org/10.1016/j.landurbplan.2016.07.002

Parseliunas, E., Sponberg, H., \& Stankevicius, Z. (2005). European level developments of flexible learning models within geographical information science for vocational training. In Selected Papers of 6th International Conference "Environmental Engineering" (Vol. 2, pp. 957-963). Vilnius: Technika.

Patel, N. R., Parida, B. R., Venus, V., Saha, S. K., \& Dadhwal, V. K. (2013). Analysis of agricultural drought using vegetation temperature condition index (VTCI) from Terra. MODIS satellite data. Environmental Monitoring and Assessment, 184(12), 7153-7163. https://doi.org/10.1007/s10661-011-2487-7

Pilesjö, P., Skidmore, A., Kooiman, A., \& Mårtensson, U. (2007, May 8-11). GEM - the first GI Erasmus Mundus masters course. Paper presented at 10th AGILE International Conference on Geographic Information Science, Aalborg, Denmark.

Ragauskas, U., Bručas, D., \& Sužiedelytè-Visockienè, J. (2016). Research of remotely piloted vehicles for cargo transportation. Aviation, 20(1), 14-20. https://doi.org/10.3846/16487788.2016.1168006

Rajabi, M. R., Mansourian, A., Pilesjo, P., \& Bazmany, A. (2014). Environmental modelling of visceral leishmaniasis by susceptibility mapping using neural networks: a case study in northwestern Iran. Geospatial Health, 9(1), 179-191. https://doi.org/10.4081/gh.2014.15

Rajabi, M. R., Pilesjo, P., Shirzadi, M. R., Fadaei, R., \& Mansourian, A. (2016). A spatially explicit agent-based modeling 
approach for the spread of cutaneous leishmaniasis disease in central Iran, Isfahan. Environmental Modelling \& Software, 82, 330-346. https://doi.org/10.1016/j.envsoft.2016.04.006

Sponberg, H., Onstein, E., Johansen, F. J., Ossiannilsson, E., Pilesjö, P., \& Mårtensson, U. (2007, November 8). Learning GIS over the Internet. Paper presented at EADTU, International Courses and Services Online Virtual Erasmus and New Generation of Open Educational Resources for a European and Global Outreach.

Sužiedelytė-Visockienè, J., Bagdžiūnaitè, R., Malys, N., \& Maliené, V. (2015). Close-range photogrammetry enables documentation of environment-induced deformation of architectural heritage. Environmental Engineering and Management Journal, 14(6), 1371-1381.

https://doi.org/10.30638/eemj.2015.149
Sužiedelytė-Visockienè, J., Bručas, D., Bagdžiūnaitè, R., Puziene, R., Stanionis, A., \& Ragauskas, U. (2016). Remotelypiloted aerial system for photogrammetry: Orthoimage generation for mapping applications. Geografie, 121(3), 349-367.

Sužiedelytè-Visockienè, J., Puzienè, R., Stanionis, A., \& Tumelienè, E. (2016). Unmanned aerial vehicles for photogrammetry: analysis of orthophoto images over the territory of Lithuania. International Journal of Aerospace Engineering, 2016, 1-9. Article ID 4141037. https://doi.org/10.1155/2016/4141037

Toomanian, A., Harrie, L., Mansourian, A., \& Pilesjo, P. (2013). Automatic integration of spatial data in viewing services. Journal of Spatial Information Science, 6. https://doi.org/10.5311/JOSIS.2013.6.87 